\title{
RESÍDUOS SÓLIDOS NOS MUNICÍPIOS E SUSTENTABILIDADE: A CRISE NOS SERVIÇOS PÚBLICOS
}

\author{
SOLID WASTE IN MUNICIPALITIES AND SUSTAINABILITY: CRISIS IN PUBLIC \\ SERVICES
}

Ilton Garcia Costa ${ }^{1}$

Gabriela Lopes Cirelli²

\section{Resumo}

O presente estudo versa sobre o necessário enfrentamento da crise socioambiental decorrente da má gestão dos resíduos sólidos, levando em conta os termos da Lei da Política Nacional de Resíduos Sólidos. Utilizou-se do método indutivo para realização de pesquisa bibliográfica e de dados estatísticos, no intuito de demonstrar que o cerne do impasse a ser suplantado - de produção desenfreada de resíduos sólidos - encontra suas raízes na lógica capitalista. Como resultados, verificou-se que o potencial econômico a ser extraído a partir da reutilização se revela imensamente inferior ao esperado, mormente pela falta de investimento no método de reciclagem, bem como pela desvalorização dos catadores de material reciclável, de modo que a adoção de uma perspectiva de manejo sustentável com inclusão social seria um possível caminho a ser trilhado. Nesse contexto, o intuito é contribuir para a reflexão sobre o impacto da gestão adequada dos resíduos sólidos no ambiente, tudo em consonância com um dos temas centrais da "Rio+20", que é a busca do desenvolvimento sustentável com erradicação da pobreza.

Palavras-chave: Crise. Política Nacional de Resíduos Sólidos. Reciclagem. Catadores de material reciclável Sustentabilidade.

\begin{abstract}
The present study deals with the necessary confrontation of the socioenvironmental crisis resulting from the bad management of solid waste, considering the terms of the National Policy on Solid Waste. It was used the inductive method to carry out bibliographic research and statistical data, in order to demonstrate that the core of the problem to be supplanted - of unrestrained production of solid waste - finds its roots in the capitalist logic. As a result, it was

\footnotetext{
1 Professor do Programa de Doutorado, Mestrado e Graduação em Direito na UENP - Universidade Estadual do Norte do Paraná, Doutor e Mestre em Direito pela PUC-SP, Pós Doutorando pela Universidade de Coimbra. líder do Grupo de Pesquisa em Constitucional, Educacional, Relações de Trabalho e Organizações Sociais - GPCERTOS da UENP, Mestre em Administração pelo UNIBERO, Vice Presidente e Presidente da Comissão de Ensino Jurídico e Comissão de Estágio - OAB SP (2013 à 2015), membro da Comissão de Direito Constitucional e Direito e Liberdades Religiosas - OAB SP, Avaliador Institucional e de Cursos pelo MEC - INEP. Membro do Comite de Área da Fundação de Pesquisa Araucária PR, Especialista em Formação Profissional - Alemanha, Matemático, Advogado. Email: iltongcosta@gmail.com

${ }^{2}$ Mestranda em Ciência Jurídica na Universidade Estadual do Norte do Paraná. Especialista em Direito Público com ênfase em Direito Constitucional pelo Centro Universitário Leonardo da Vinci. Procuradora Jurídica da Câmara Municipal de Cambará/PR e conciliadora dos Juizados Especiais Cíveis e Criminais da Comarca de Ribeirão Claro/PR. E-mail: gabilc_4@hotmail.com
} 
verified that the economic potential that could be extracted from the re-use shows to be much lower than expected, mainly due to the lack of investment in the recycling method, as well as the devaluation of recyclable waste pickers, so that the adoption of a sustainable management perspective with social inclusion would be a possible path to be followed. In this context, the intention is to contribute to the reflection on the impact of the proper management of solid waste in the environment, all in line with one of the central themes of "Rio + 20", which is the search for sustainable development with eradication of poverty.

Keywords: Crisis. National Policy on Solid Waste. Recycling. Waste Picker. Sustainability.

\section{INTRODUÇÃO}

O presente artigo pretende discorrer acerca da evidente crise do serviço público de administração dos resíduos sólidos - um dos maiores desafios das cidades brasileiras - a despeito de a abordagem desse problema ainda estar longe de ser realizada a contento, já que, na maior parte das vezes, são tratadas apenas suas consequências, sem uma análise crítica de suas causas.

Essa discussão emerge, sobretudo, da necessidade de se conciliar - em certa medida o desenvolvimento com a proteção dos ecossistemas, o que exige práticas sustentáveis na concretização desse equilíbrio. Entretanto, conforme se verá adiante, a utilização de métodos como a reciclagem não se dá de modo expressivo como deveria, eis que a grande maioria ainda se vale de outros meios considerados retrógrados, com prejuízos infindáveis ao ambiente, consistentes na utilização de lixões, por exemplo. Em razão disso, pretende-se dissecar as metas estabelecidas pela Lei da Política Nacional de Resíduos Sólidos, cuja finalidade é contribuir para a eliminação dos lixões por meio de instrumentos de planejamento nos níveis nacional, estadual, microrregional, intermunicipal e metropolitano e municipal, além de impor que os particulares elaborem seus Planos de Gerenciamento de Resíduos Sólidos.

Nesse passo, a fim de conceber os possíveis caminhos para uma gestão sustentável dos resíduos sólidos, o estudo cuidará - em um primeiro momento - de tratar dos termos consumo, consumismo, desperdício, além dos principais aspectos da supramencionada lei, que engloba, inclusive, o conjunto de instrumentos que estimulam o uso da reciclagem e da reutilização dos resíduos sólidos (aquilo que tem valor econômico e pode ser reciclado ou reaproveitado) e a destinação ambientalmente adequada dos rejeitos (aquilo que não pode ser reciclado ou reutilizado).

Superada essa análise, o artigo avançará no sentido de se tentar aferir se existe ou não a efetiva aplicação da Política Nacional de Resíduos Sólidos no cenário atual, o que demanda um 
olhar mais crítico acerca da postura dos municípios em face de seu dever de proporcionar as condições necessárias para a instituição de "cidades sustentáveis".

Outrossim, almeja-se analisar a relevância de ações e/ou proposições que visam a atingir esse patamar de otimização do serviço essencial de gestão dos resíduos sólidos, tudo com vistas a encontrar uma via de enfrentamento da crise civilizatória instalada, já que as consequências de sua má administração são fatalmente prejudiciais não só ao ambiente, mas também à saúde da população.

Frente à complexidade do tema em questão, estamos longe de ter uma resposta milagrosa a essa crise; entretanto, esse enfrentamento abrange também a preocupação com os impactos socioambientais oriundos da má administração dos resíduos sólidos, sendo certo que a adoção de uma perspectiva de manejo sustentável com inclusão social seria um possível caminho a ser trilhado rumo ao alcance de um ideal de sustentabilidade, aliado à erradicação da pobreza.

Nesse sentido, o intuito é contribuir para a constante tentativa de aperfeiçoamento da gestão dos serviços de resíduos sólidos nos municípios, o que demanda a revisão das práticas vigentes - sobretudo a necessidade de valorização dos catadores como chave para inclusão social e viabilização da logística reversa dos resíduos para reintrodução em novos ciclos produtivos -, medidas capazes de amenizar os impactos negativos que os resíduos sólidos podem ocasionar à higidez do ambiente local.

\section{A CRISE AMBIENTAL DA SOCIEDADE "LÍQUIDO-MODERNA", O CONSUMISMO E O DESPERDÍCIO: O SISTEMA DE CONSUMO ATUAL E SUA INFLUÊNCIA NA CRESCENTE QUANTIDADE DE RESÍDUOS PRODUZIDOS}

De início, cumpre referir que - nos primórdios da existência humana e durante milhares de anos - a inexistência de meios técnicos e a reduzida densidade populacional obstaram a que o ser humano desvirtuasse a sua relação com os fenômenos naturais.

Ocorre que - com o advento da Revolução Industrial - iniciou-se a interferência no equilíbrio desses fatores naturais, que começaram a sentir desvios incompatíveis com a sua regeneração e sustentação natural. Tanto é assim que tais fatores - associados ao aumento da densidade populacional - ameaçam a existência da própria humanidade, tornando-se "cada vez mais paradoxal a constatação da desproporção crescente entre a fragilidade do objeto da ação 
humana, os fatores naturais e o poder dos meios capazes de destruí-los" (CUNHA, 2004, p. 109110).

Infere-se, assim, que os elementos que caracterizam a crise ambiental da sociedade de risco - erguida a partir da Revolução Industrial no século XVII - trouxe a ideia de progresso e desenvolvimento, encontrando seus limites, entretanto, na questão ambiental, tendo em vista que os recursos são finitos e a natureza tem seus limites de exploração.

De um modo geral, urge destacar que a ideia de degradação ambiental, portanto, manifesta-se como sintoma de uma crise de civilização marcada pelo modelo de modernidade regido pelo predomínio do desenvolvimento da razão tecnológica sobre a organização da natureza (LEFF, 2001, p. 343).

Nesse viés, dispõe Bauman (2007, p. 15) que hoje vivemos em uma modernidade líquida ou sociedade "líquido-moderna", segundo a qual a "velocidade, e não a duração, é o que importa". Esse raciocínio reflete uma série de impasses na seara ambiental, já que - nesse sentido - tudo é fugaz e efêmero, inclusive a própria vida, considerada, para o mesmo autor, "uma vida precária, vivida em condições de incerteza constante" (BAUMAN, 2007, p. 8).

Essa sociedade se acostumou ao descartável, o que tem provocado a superprodução de resíduos, já que encara os recursos naturais como se esses fossem inesgotáveis. Desse modo, nota-se que a globalização e - por conseguinte - a sociedade de risco (efeito da pósmodernidade) fez estremecer as estruturas da ordem jurídica, sem as abalar, mas também porque fez repensar seus paradigmas, consistindo - por isso - num dos principais fatores de que vai depender a eficácia do direito no futuro, a sua utilidade e, por derradeiro, a sua própria sobrevivência (CUNHA, 2004, p. 113).

Nesse sentido, verifica-se que o problema reside no fato de que o modelo de produção capitalista é voltado à manutenção desse ritmo que prioriza o consumo, pautando-se no desperdício e excesso de produção de resíduos, impasse que demanda - em primeiro lugar uma mudança de mentalidade da sociedade e de seu modo de produzir a vida. A revisão urgente desse paradigma não se trata de tarefa fácil; entretanto, é possível visualizar mudanças sob a ótica do desenvolvimento sustentável, uma vez que dele depende a existência harmoniosa.

Lembram Garcia e Campidelli (2016, p. 93) que o fator mais relevante deste compromisso de sustentabilidade é o seu alcance mundial sem precedentes, uma vez que foi recebido por todos os países - sem distinção - com um único objetivo: buscar o 
desenvolvimento sustentável aliado à vida digna, de maneira que se tenha um ambiente no qual a vida possa prosperar, que conte com o mínimo para se viver dignamente.

Forçoso mencionar que algumas práticas refletem diretamente na manutenção desse modelo que estimula a superprodução de resíduos, como ocorre com o caso da obsolescência planejada, que - conquanto se trate de estratégia indesejada - tem sido bastante utilizada nos dias atuais, valendo lembrar que possui íntima relação com o que se vem a chamar de capitalismo pós-industrial; conforme Harvey (1992), essa prática detona com as ideias de durabilidade, qualidade e estocagem.

Sabe-se que o sistema econômico vigente se desenvolve a serviço do capital, de tal sorte que seus efeitos são devastadores por destruir e esgotar a natureza a fim de aumentar a acumulação de riquezas privadas: o crescimento dessas últimas se torna proporcional ao aumento da destruição da natureza. Nesse tocante, vê-se que o fenômeno da obsolescência planejada se trata de uma tecnologia que faz com que tudo acabe em lixo, já que - quanto mais rápida e passageira for a vida dos produtos - maior será o descarte.

Segundo Padilha (2013), esse modelo de sociedade - baseado na estratégia da obsolescência planejada - tem sido determinante no esgotamento dos recursos naturais (que ocorre na etapa da produção) e no excesso de resíduos (que ocorre na etapa do consumo e do descarte).

No intuito de arrolar hipóteses de como combater práticas como a obsolescência planejada, Cortez e Ortigoza (2009, p. 60) asseveram que

Os padrões de produção devem ser modificados, de um lado, por meio da substituição de matérias-primas e matrizes energéticas e, de outro, combatendo o desperdício, a obsolescência planejada dos produtos e sua descartabilidade. Além disso, os padrões de consumo, segundo o discurso ecológico original, devem ser drasticamente reduzidos, estabelecendo-se não apenas um piso, mas também um teto de consumo, especialmente referindo-se ao consumo ostentatório das sociedades afluentes existentes tanto nos países de primeiro quanto nos de terceiro mundo.

A fim de se compreender do que se trata esse padrão de consumo, Simões (2016, s.p.), citando Marques, elucida que consumir é, antes de tudo, comprar, despender parcela econômica de capital para adquirir uma coisa, o que faz girar a economia, uma vez que quanto mais se consome, mais renda há, mais dinheiro circula, criando empregos e renda.

Nesse ínterim, insta reconhecer o impacto de certos termos para melhor compreensão do presente estudo, o que demanda uma tentativa de sua definição: em primeiro lugar, entende-se por consumo o uso dos bens em razão de necessidade ou para fins de sobrevivência, o qual, segundo Bauman (2008, p. 37): 
Aparentemente, o consumo é algo banal, até mesmo trivial. É uma atividade que fazemos todos os dias, por vezes de maneira festiva, ao organizar um encontro com os amigos, comemorar um evento importante ou para nos recompensar por uma realização particularmente importante - mas a maioria das vezes é de modo prosaico, rotineiro, sem muito planejamento antecipado nem reconsiderações.

Por sua vez, verifica-se o consumismo quando o gasto se dá em produtos sem utilidade imediata, os quais - em outras palavras - são considerados supérfluos:

De maneira distinta do consumo, que é basicamente uma característica e uma ocupação dos seres humanos como indivíduos, o consumismo é um atributo da sociedade. Para que uma sociedade adquira esse atributo, a capacidade profundamente individual de querer, desejar e almejar deve ser, tal como a capacidade de trabalho na sociedade de produtores, destacada ("alienada") dos indivíduos reciclada/reificada numa força externa que coloca a "sociedade de consumidores" em movimento e a mantém em curso como uma forma específica de convívio humano, enquanto ao mesmo tempo estabelece parâmetros específicos para as estratégias individuais de vida que são eficazes e manipula as probabilidades de escolha e conduta individuais. (BAUMAN, 2008, p. 41).

Tudo isso ainda diz pouco sobre o conteúdo da "revolução consumista": a questão que exige uma investigação mais atenta diz respeito ao que "queremos", "desejamos" e "almejamos", e como as substâncias de nossas vontades, desejos e anseios estão mudando no curso em consequência da passagem ao consumismo. É comum se pensar (embora seja possível mostrar que de maneira incorreta) que aquilo que os homens e as mulheres lançados ao modo de vida consumista desejam e almejam é - em primeiro lugar - a apropriação, a posse e a acumulação de objetos, valorizados pelo conforto que proporcionam e/ou respeito que outorgam a seus donos. (BAUMAN, 2008, p. 42)

Na medida em que a publicidade e propaganda estimulam mais o "ter" que o "ser", os hábitos consumistas passam a ser cada vez mais comuns, já que - segundo essa ótica supervaloriza-se mais o poder de compra das pessoas do que seu valor inerente à sua condição de ser humano.

Baudrillard (2008, p. 25-26) explica que a mídia instiga o consumo, de maneira que:

As comunicações de massa não nos oferecem a realidade, mas a vertigem da realidade [...] Vivemos desta maneira ao abrigo dos signos e na recusa do real. Segurança miraculosa: ao contemplarmos as imagens do mundo, quem distinguirá esta breve irrupção da realidade do prazer profundo de nela não participar. A imagem, o signo, a mensagem, tudo o que consumimos, é a própria tranquilidade selada pela distância ao mundo e que ilude, mas do que compromete a alusão violenta ao real.

Essa ideia de prevalência do "ter" em detrimento do "ser" é própria da sociedade de consumo, a qual - além de se revelar instável por sua própria natureza - tem o consumo por 
elemento central na formação da identidade: consumir, assim, vai muito além da satisfação de necessidades, já que passa a ter um peso primordial na construção das personalidades.

Nesse diapasão, Bauman (2014) sustenta - em entrevista dada ao jornal espanhol La Vanguardia - que "não se pode escapar do consumo: faz parte do seu metabolismo! O problema não é consumir; é o desejo insaciável de continuar consumindo [...]". O mesmo autor, logo na sequência, lembra que: "desde o paleolítico, os humanos perseguem a felicidade, mas os desejos são infinitos. As relações humanas são sequestradas por essa mania de apropriar-se do máximo possível de coisas" (BAUMAN, 2014).

Sob esse prisma, depreende-se que a sociedade atual é fomentada por uma nítida obsessão pelo ato de comprar, já que as pessoas passam a ser niveladas de acordo com seu maior ou menor poder de compra: quanto menor esse poder, maior sua humilhação perante os demais; assim, quem consegue consumir mais, se livrará da exclusão.

Consequentemente, o que é consumido transformar-se-á em lixo, sendo certo que em virtude desse hábito de consumo desenfreado - nos termos da visão de Bauman, acaba-se por viver hoje numa "cultura do lixo". Para o autor (2007, p. 17), "o lixo é o principal e comprovadamente o mais abundante produto da sociedade moderna de consumo". Isso porque, segundo ele, entre as indústrias da sociedade de consumo, a de produção de lixo é a mais sólida e imune a crises.

Em virtude disso, há quem se utilize do termo "sociedade de consumo" para designar essa realidade, que também se trata de uma das tentativas para entender as mudanças que vêm ocorrendo nas sociedades contemporâneas e se refere à importância que o consumo tem recebido na construção das relações sociais e na formação e fortalecimento das nossas identidades.

É, justamente, neste atual contexto de sociedade do consumo, em que Bauman (2005, p. 89) afirma que o triunfo global da modernidade é a crise aguda da indústria de remoção do lixo humano: como o volume de refugo humano supera a atual capacidade gerencial, há uma expectativa plausível de que a modernidade, agora planetária, se sufoque em seus próprios dejetos, que ela não pode assimilar nem suprir.

Conforme dispõe Magalhães (2002, p. 41), a característica central dessa sociedade industrial é o desperdício, o uso indiscriminado dos recursos naturais, sem a preocupação com o seu futuro, se eles estarão preservados para as novas gerações. A grande orientação da sociedade industrial é o uso desenfreado de um recurso natural e o seu descarte imediato, tão logo o uso é feito. 
A alusão a que Bauman faz acerca do lixo, em sua obra "Vida Líquida", faz com que se chegue à conclusão de que a sua remoção se trata de um dos dois principais desafios que a vida líquida precisa enfrentar e resolver, considerando que a escravidão consumista é a realidade massiva na atual "cultura do lixo".

Nesse aspecto, relata que: "a vida talvez seja sempre um viver-para-a-morte. Mas, para os que vivem na líquida sociedade moderna, a perspectiva de viver-para-o-depósito-de-lixo pode ser a preocupação mais imediata." (BAUMAN, 2007, p. 17-18)

Consoante se pode imaginar, a sociedade contemporânea ou "líquido-moderna" se identifica eminentemente em razão de seu excessivo poder de consumo e se caracteriza pela cultura do desperdício, o que provoca a situação caótica e alarmante quando essa mesma sociedade se desfaz do próprio lixo por ela produzido: nesse cenário, os serviços públicos, as relações sociais, a natureza, o tempo e o próprio corpo humano transformam-se em mercadorias.

Trata-se de uma sociedade que não possui uma consciência madura acerca do ideal da sustentabilidade, já que enxerga a durabilidade da vida como algo efêmero; nesse viés, o desenvolvimento da noção de sociedade do risco global compreende os riscos como projeções espaciais e temporais de estados de deficiência na qualidade do conhecimento: insuficiência informativa, deficiência cognitiva e incerteza como padrões definidores da extensão dos efeitos de nossas decisões irresponsáveis (AYALA, 2004, p. 238).

Dessa maneira, o nível e o estilo de consumo tornam-se a principal fonte de identidade cultural, de participação na vida coletiva, de aceitação em um grupo e de distinção com os demais, estando presente nas diversas esferas da vida social, econômica, cultural e política.

Nas palavras de Zaneti et. al. (2009, p. 184), o "funcionamento do sistema capitalista atual tende a apagar na prática a distinção entre consumo e destruição, em decorrência da sua contradição intrínseca entre valor de uso e valor de troca". Nessa linha de raciocínio, "o uso da noção de desenvolvimento sustentável, sem qualquer esforço crítico quanto à lógica do sistema do capital, se constitui, pura e simplesmente, numa afirmação inconsequente das práticas produtivas deste sistema".

No que tange à produção de lixo no cenário brasileiro, cumpre mencionar que "aproximadamente $80 \%$ da população vive em áreas urbanas ao mesmo tempo em que a geração de resíduos sólidos per capita está aumentando cada vez mais, assim como sua complexidade e periculosidade" (JACOBI, 2012, p. 31). 
Grande parte dos municípios vem enfrentando sérios problemas afetos não só à geração de resíduos, mas também à falta de conhecimento sobre as possíveis alternativas para seu destino final, o que provoca diversos transtornos à população e ao meio ambiente. Isso porque - com o crescente incentivo do consumo da sociedade, gerado pelo modo capitalista de produzir a vida - o processo de aquisição e descarte aumenta significativamente o volume de resíduos sólidos nos lixões em todo o país, o que gera a denominada crise de gestão dos resíduos sólidos.

Como alerta Kennedy (1996, p. 112), a crise ambiental (que inclui a do lixo) que se enfrenta hoje é "qualitativa e quantitativamente diferente de qualquer coisa acontecida antes, simplesmente porque tantas pessoas vêm causando danos ao ecossistema mundial neste século que esse sistema como um todo - e não apenas suas várias partes - corre perigo".

Observa-se um nítido aumento na produção de resíduos sólidos, tanto em quantidade como em diversidade, principalmente nos grandes centros urbanos. Além do acréscimo na quantidade, os resíduos produzidos atualmente passaram a abrigar em sua composição elementos sintéticos e perigosos aos ecossistemas e à saúde humana, em virtude das novas tecnologias incorporadas ao cotidiano.

Em nível mundial, verifica-se que - a cada ano - 1,3 bilhão de toneladas de lixo são produzidas em cidades do mundo todo. De acordo com o Programa da ONU para o Meio Ambiente (PNUMA), em 2025, o número chegará aos 2,2 bilhões, colocando-nos em uma espécie de crise global de lixo em que o principal vilão é a má gestão por parte dos governos (PNUMA, 2012).

A fim de melhor elucidar o quadro caótico no qual se observa a realidade brasileira, a Associação Brasileira de Empresas de Limpeza Pública e Resíduos Especiais (ABRELPE) e o Instituto Brasileiro de Geografia e Estatística (IBGE) disponibilizam dados estatísticos que permitem o vislumbre da realidade brasileira, no que diz respeito à produção de resíduos sólidos urbanos.

Os números assustam: a geração de Resíduos Sólidos Urbanos (RSU) per capita é de 1,040 kg por dia, enquanto a geração total é de 214.405 toneladas por dia, o que revela um total anual de quase 78,3 milhões de toneladas no país, resultante de uma queda de $2 \%$ no montante gerado em relação ao ano de 2015, pela primeira vez desde que começou a ser feito o referido levantamento (ABRELPE, 2016), conforme Tabela 1 a seguir: 
Tabela 1: Geração de Resíduos Sólidos Urbanos (RSU) no Brasil

\begin{tabular}{|c|c|c|}
\hline Ano & Geração Total de RSU (t/dia) & Geração de RSU per capita * \\
\hline 2015 & 218.874 & 1,071 \\
\hline 2016 & 214.405 & 1,040 \\
\hline Percentual & $-2,0 \%$ & $-2,9 \%$ \\
\hline & Fonte: pesquisa ABRELPE e IBGE & $*(\mathrm{~kg} / \mathrm{hab} /$ dia $)$ \\
\hline
\end{tabular}

Ocorre que essa queda de geração não se trata de reflexo da redução consciente de consumo, nem da melhoria na coleta e na destinação. Como consequência desse quadro, houve corte de empregos e aumento de cidades que passaram a usar lixões para destinação de seus resíduos: 1.552 cidades em 2015 para 1559 em 2016; sendo que, no total, 59,8\% das cidades brasileiras fazem uso de destinos considerados inadequados(Tabela 2) para descarte de lixo, além disso, apenas 69,6\% das cidades tem alguma coleta seletiva (Tabela 3), (ABRELPE, 2016), dado gritante se comparado a países desenvolvidos, como Alemanha, Japão e Suécia (SENADO FEDERAL, 2014, p. 52-53). Veja-se os dados:

Tabela 2: Quantidade de Municípios por Tipo de Disposição Final Adotada

\begin{tabular}{|c|c|c|c|c|c|c|c|}
\hline Disposição Final & Brasil & Norte & Nordeste & Centro Oeste & Sudeste & Sul & Brasil \\
\hline Ano & 2015 & 2016 & 2016 & 2016 & 2016 & 2016 & 2016 \\
\hline Aterro Sanitário & 2244 & 92 & 458 & 161 & 822 & 706 & 2239 \\
\hline Aterro Controlado & 1774 & 112 & 500 & 148 & 644 & 368 & 1772 \\
\hline Lixão & 1552 & 246 & 836 & 158 & 202 & 117 & 1559 \\
\hline Brasil & 5570 & 450 & 1794 & 467 & 1668 & 1191 & 5570 \\
\hline \multicolumn{7}{r}{ Fonte: pesquisa ABRELPE e IBGE } \\
\end{tabular}

Tabela 3: Quantidade de Municípios com iniciativas de coleta seletiva

\begin{tabular}{|c|c|c|c|c|c|c|c|c|c|c|c|c|}
\hline Região & Norte & Norte & NE & NE & $\begin{array}{c}\text { Centro } \\
\text { oeste }\end{array}$ & $\begin{array}{c}\text { Centro } \\
\text { oeste }\end{array}$ & SE & SE & Sul & Sul & Brasil & Brasl \\
\hline Ano & 2015 & 2016 & 2015 & 2016 & 2015 & 2016 & 2015 & 2016 & 2015 & 2016 & 2015 & 2016 \\
\hline Sim & 258 & 263 & 884 & 889 & 200 & 202 & 1450 & 1454 & 1067 & 1070 & 3859 & 3878 \\
\hline Não & 192 & 187 & 910 & 905 & 267 & 265 & 218 & 214 & 124 & 121 & 1711 & 1692 \\
\hline Total & 450 & 450 & 1794 & 1794 & 467 & 467 & 1668 & 1668 & 1191 & 1191 & 5570 & 5570 \\
\hline \multicolumn{8}{|c|}{ Fonte: pesquisa ABRELPE e IBGE } \\
\hline
\end{tabular}

O montante coletado em 2016 foi de 71,3 milhões de toneladas, o que registrou um índice de cobertura de coleta de 91\% para o país, pequeno avanço comparado ao ano anterior, e que evidencia que 7 milhões de toneladas de resíduos não foram objeto de coleta e, consequentemente, tiveram destino impróprio. 
A disposição final dos Resíduos Sólidos Urbanos (RSU) coletados demonstrou piora comparado ao índice do ano anterior, de $58,7 \%$ para $58,4 \%$ ou 41,7 milhões de toneladas enviadas para aterros sanitários. O caminho da disposição inadequada continuou sendo trilhado por 3.331 municípios brasileiros, que enviaram mais de 29,7 milhões de toneladas de resíduos, correspondentes a $41,6 \%$ do coletado em 2016, para lixões ou aterros controlados, que não possuem o conjunto de sistemas e medidas necessários para proteção do meio ambiente contra danos e degradações (ABRELPE, 2016).

Tabela 4: Disposição final de RSU no Brasil por Tipo de Destinação (T/DIA)

\begin{tabular}{|c|c|c|c|}
\hline Ano & Aterro Sanitário & Aterro Controlado & Lixão \\
\hline 2015 & 116.631 & 47.942 & 34.177 \\
\hline 2015 & $58,7 \%$ & $24,1 \%$ & $17,2 \%$ \\
\hline 2016 & 114.189 & 47.315 & 33.948 \\
\hline 2016 & $58,4 \%$ & 24,2 & $17,1 \%$ \\
\hline
\end{tabular}

Nessa senda, o consumidor utiliza o bem ou serviço necessitado e - ao término desta etapa (assim como também ao término das etapas anteriores) - gera produtos desnecessários. De acordo com dados apresentados pelo Instituto Akatu em 2009, 1/3 (um terço) de tudo o que compramos vai para o lixo:

No Brasil, aproximadamente um terço de todos os alimentos comprados em uma casa é desperdiçado. Junto com eles, todas as suas embalagens, toda a água e energia usadas na sua produção, todo o $\mathrm{CO} 2$ emitido em sua produção e transporte, etc; são também jogados fora gerando inúmeros impactos negativos para a sociedade, a economia e o meio ambiente.

Observa-se que a geração de resíduos não ocorre somente na fase final da cadeia do consumo, mas também nas etapas anteriores, valendo ressaltar que as indústrias são grandes responsáveis por sua superprodução e, muitas vezes, por seu descarte inadequado; quando se desfaz de algo, devem ser levadas em conta toda a água e toda a energia utilizadas em sua produção, ou seja, todo o impacto ambiental causado até esse bem chegar à residência do consumidor.

O uso e descarte desordenados das embalagens dos produtos, do mesmo modo, geram um grande volume de resíduos sólidos, associados ao impacto ambiental, o que demanda a utilização de meios alternativos para reduzir tais impactos - a reutilização e reciclagem das embalagens - além do uso de materiais biodegradáveis. 
Considerando esse panorama demonstrado em linhas anteriores, que dá conta da existência de uma verdadeira crise em virtude da superprodução e má gestão dos resíduos sólidos, torna-se medida de rigor tratar, no próximo momento, da Política Nacional de Resíduos Sólidos (PNRS) e seus desdobramentos.

\section{A POLÍTICA NACIONAL DE RESÍDUOS SÓLIDOS: A LEI N. 12.305/2010 COMO FERRAMENTA NO ENFRENTAMENTO DOS PRINCIPAIS PROBLEMAS AMBIENTAIS, SOCIAIS E ECONÔMICOS DECORRENTES DO MANEJO INADEQUADO DOS RESÍDUOS SÓLIDOS}

Propõe-se - a partir dos elementos trazidos pela Lei de Política Nacional de Resíduos Sólidos (PNRS, Lei n. 12.305/2010) - uma reflexão acerca dos atuais padrões irresponsáveis de consumo e dos riscos ambientais gerados pelas práticas inadequadas de gestão e destinação dos resíduos sólidos, a fim de que posteriormente se torne possível apresentar - no terceiro capítulo - soluções hábeis a minimizar a produção desses.

De início, não é demasiado frisar que proteger o meio ambiente tem ligação direta com a manutenção da vida humana, pelo que pode ser elevado ao status de direito fundamental:

Os direitos fundamentais correspondem aos valores mais importantes para a realização do ser humano, que se traduzem nas principais normas jurídicas da comunidade. Assim, se o direito positivo, num ambiente democrático, reflete as expectativas jurídicas da comunidade, um conceito adequado de direitos fundamentais deve basear-se no direito vigente. (ROTHENBURG, 2014, p. 41)

Não é necessário muito esforço para se observar que o processo de urbanização proporcionou o desenvolvimento e melhora da vida da humanidade, nada obstante tenha "deixado muita sujeira pelo caminho". Conquanto a latente crise ambiental instalada não se restrinja à realidade brasileira, o estudo priorizará esse enfrentamento em nível local; conforme se pôde extrair do primeiro momento desse trabalho, os fatores como o desenvolvimento econômico, o crescimento populacional, a urbanização e a revolução tecnológica vêm sendo acompanhados por alterações no estilo de vida e nos modos de produção e consumo da população.

Verifica-se, assim, que no contexto urbano brasileiro, os problemas ambientais têm se multiplicado, e sua lenta resolução tem se tornado de conhecimento público pelo seu impacto inclusive as dificuldades da gestão dos resíduos sólidos e interferência crescente do despejo 
inadequado de resíduos sólidos em áreas potencialmente degradáveis em termos ambientais (JACOBI, 2006, p. 9).

Nessa toada, argumentam COLEN e GOMES (2017, p. 267):

Tormentosa a questão acerca da produção de resíduos sólidos em decorrência de toda e qualquer atividade humana. Em que pese tratar-se de um problema universal, haja vista que, não raro, são noticiadas intercorrências geradas pelo despejo de resíduos em alto-mar por navios de nacionalidades diversas, no Brasil, a promulgação da Lei no 12.305/2010 - Lei de Política Nacional de Resíduos Sólidos - LPNRS provocou um necessário despertar para o problema e pela busca de soluções.

Nesse diapasão, cumpre mencionar que - muito embora sejam utilizados, normalmente, como sinônimos - os termos referentes ao tema em questão (lixo, resíduos sólidos, rejeitos) possuem distinção de significados; nesse sentido, resíduos sólidos, segundo a Lei n. 12.305/2010, consistem em:

[...] material, substância, objeto ou bem descartado resultante de atividades humanas em sociedade, a cuja destinação final se procede, se propõe proceder ou se está obrigado a proceder, nos estados sólido ou semissólido, bem como gases contidos em recipientes e líquidos cujas particularidades tornem inviável o seu lançamento na rede pública de esgotos ou em corpos d'água, ou exijam para isso soluções técnica ou economicamente inviáveis em face da melhor tecnologia disponível. (BRASIL, 2010)

Ainda nos termos da referida lei, os rejeitos, por sua vez, são os resíduos sólidos que não apresentem outra possibilidade que não a disposição final ambientalmente adequada, depois de esgotadas todas as possibilidades de tratamento e recuperação por processos tecnológicos disponíveis e economicamente viáveis (BRASIL, 2010).

Calha registrar, ainda, que, segundo o que consta do Novo Dicionário Aurélio, a palavra lixo - utilizada no primeiro capítulo - possui os seguintes significados: "1. Aquilo que se varre da casa, do jardim, da rua, e se joga fora; entulho. 2. Tudo o que não presta e se joga fora. 3. Sujidade, sujeira, imundície. 4. Coisa ou coisas inúteis, velhas, sem valor. 5. Ralé" (FERREIRA, 2001, p. 174).

Veja-se que a impressão dada pelo significado etimológico da palavra em comento é a de que se consideraria como lixo algo sem valor, sem importância e que deveria ser jogado fora. Ocorre que essa ótica - ainda impregnada pelo espírito imediatista do ser humano - está inegavelmente equivocada, uma vez que é possível sua reutilização, desde que observadas as disposições constantes da legislação acima indicada, a qual exige que esta ocorra de acordo com o plano municipal de gestão integrada de resíduos sólidos ou com plano de gerenciamento de resíduos sólidos. 
Destarte, verifica-se que não cabe mais a denominação de lixo para aquilo que sobra no processo de produção ou de consumo; esse entendimento - consistente em deixar de tratar como inútil esses elementos - é o que permite avançar na construção de um novo paradigma.

A questão do gerenciamento dos resíduos sólidos urbanos passou a ser devidamente tratada com o advento da Lei n. 12.305/2010, a qual - ao trazer novas alternativas para a destinação adequada dos insumos - representou um marco regulatório para tal problemática, tendo considerado o bem-estar social e - ao mesmo tempo - a sustentabilidade sob os pontos de vista ambiental, social e econômico.

Consoante lembra Amado (2014, p. 810), após tramitar por mais de 20 anos no Congresso Nacional, finalmente foi aprovado o Projeto n. 354/1989, por intermédio da Lei n. 12.305, de 02.08.2010 - que instituiu a Política Nacional dos Resíduos Sólidos (PNRS) e integra a Política Nacional do Meio Ambiente - articulando-se com a Política Nacional de Educação Ambiental e com a Política Federal de Saneamento Básico.

Impende destacar que as regras jurídicas que se aplicam aos resíduos sólidos continuam a ter gênese constitucional em face da tutela jurídica do meio ambiente artificial, de tal sorte que a Lei n. 12.305/2010 instituiu tão somente normas destinadas a fixar no plano inferior "princípios, objetivos e instrumentos", bem como "diretrizes relativas à gestão integrada e ao gerenciamento de resíduos sólidos, incluídos os perigosos, às responsabilidades dos geradores e do poder público e aos instrumentos econômicos aplicáveis" (art. 1ํ), o que deverá ser feito em harmonia com os Planos Diretores (art. 182, §1으, da CF) e sempre com a finalidade de estabelecer uma política de desenvolvimento adaptada à garantia do direito a cidades sustentáveis (art. 20, I, da Lei n. 10.257/2001 - Estatuto da Cidade) (FIORILLO, 2011, p. 370).

Como explica Machado (2013, p. 633), a referida lei foi elaborada tendo como fundamento a Constituição da República, em seu art. 24, VI (proteção do meio ambiente e controle da poluição) e VIII (responsabilidade por dano ao meio ambiente e ao consumidor); utilizou-se, assim, da competência suplementar dos Estados (art. 24, §2ํㅡ, da CF). Assim, há de se compreender que a precitada lei deixou para os Estados, por exemplo, estabelecer normas sobre a metodologia a ser utilizada no tratamento dos resíduos e dos rejeitos. No que couber e havendo "interesse local", os Municípios poderão intervir suplementando a legislação federal e estadual de resíduos sólidos (art. 30, I e II da CF), razão pela qual a União não tem competência de legislar privativamente sobre resíduos sólidos.

A PNRS determina - dentre outras - ações como a extinção dos lixões do país e substituição por aterros sanitários, além da implantação da reciclagem, reutilização, 
compostagem, tratamento dos resíduos sólidos e coleta seletiva nos municípios. Nesse aspecto, COLEN e GOMES (2017, p. 271) lembram que - não obstante estivesse previsto pelo art. 54 da Lei de PNRS que a disposição final ambientalmente adequada dos rejeitos deveria ser implantada no período de até quatro anos após a data de sua publicação (03.08.2010) - tal previsão não se concretizou, motivo pelo qual o Senado aprovou em 01.07.2015 projeto que prorroga o prazo para as cidades brasileiras adequarem a gestão que fazem do lixo às regras da PNRS, estendendo o limite da data para a extinção dos lixões nos municípios em prazos escalonados de acordo com o município, entre 2018 e 2021.

Independente de essa alternativa se revelar meramente paliativa, já que apenas prorroga o prazo e não traz possíveis soluções, cabe salientar que a PNRS não se resume ao fim dos lixões, mas - dentre outras providências - também aos 3 (três) "erres": reduzir, reutilizar e reciclar e, ainda, à chamada responsabilidade compartilhada, de maneira que governos, empresários e consumidores deveriam agir em conjunto em prol da proteção ambiental.

Importante frisar que os resíduos sólidos são grandes responsáveis pelas alterações climáticas, uma vez que também contribuem para a emissão dos gases do efeito estufa. 0 gerenciamento inadequado dos resíduos sólidos urbanos gera diretamente outros impactos importantes - ambientais e na saúde da população - o que faz com que os resíduos sólidos sejam considerados como um grave problema ambiental contemporâneo, haja vista a tendência de crescimento do problema.

Conforme já mencionado, o art. 6이 da lei estabelece uma listagem de seus princípios que - segundo ensina Machado (2013, p. 633) - necessitam ser interpretados com permanente integração com todo o corpo da lei, principalmente levando-se em conta as definições (art. 3ำ), os objetivos (art. 7ํ)), as disposições gerais (art. 4으), os instrumentos (art. 8ㅇ) e as disposições preliminares do Capítulo I do Título III.

O princípio inserto no art. 60 , VIII, do qual se tratará no próximo tópico, afirma diretamente que o resíduo sólido reutilizável e reciclável tem valor econômico, além de acrescentar, ainda, que esse bem tem um valor social, que gera trabalho e renda e, finalmente, registra que a reutilização e a reciclagem são verdadeiras promotoras da cidadania.

Machado (2013, p. 633) ainda aponta que merece elogio essa estruturação da lei, pois seus aplicadores passam a ter orientação eficiente e segura para a própria interpretação do texto legal e de sua regulamentação.

De inegável relevância e que deve ser trazida à baila nessa oportunidade é a existência de uma ordem de prioridade na gestão e gerenciamento dos resíduos sólidos, que se trata de 
uma ordem com força legal, conforme art. 9o da lei em comento: coloca-se em primeiro lugar a "não geração" de resíduos sólidos, já que a primeira preocupação de qualquer empreendimento, público ou privado, deve ser a de não gerar resíduos. No entanto, é interessante que entre os demais elementos mencionados no mesmo art. 9o continua havendo uma "ordem de prioridade", na sequência em que constam da lei: redução de resíduos, reutilização de resíduos, reciclagem de resíduos e disposição final ambientalmente adequada dos rejeitos. (MACHADO, 2012, p. 25)

Oportuno ressaltar que a PNRS previu que a adoção de programas e ações de educação ambiental (art. 19, inciso X, da Lei 12.305/2010) seria parte integrante do conteúdo mínimo do plano municipal de gestão integrada de resíduos sólidos, donde decorre a inafastabilidade dessa, como poderoso instrumento viabilizador da compreensão acerca das etapas envolvidas no processo produtivo de qualquer bem, da relação umbilical desse processo com a produção de resíduos e dos riscos que tais resíduos representam para o meio ambiente (COLEN; GOMES, 2017, p. 280).

Nesse diapasão, outro ponto que merece ser salientado é o que trata do instituto da logística reversa, que - malgrado ainda se trate de um conceito em permanente construção sua definição legal se encontra insculpida no art. 3ำ, XII, da Lei da PNRS:

[...] instrumento de desenvolvimento econômico e social caracterizado por um conjunto de ações, procedimentos e meios destinados a viabilizar a coleta e a restituição dos resíduos sólidos ao setor empresarial, para reaproveitamento, em seu ciclo ou em outros ciclos produtivos, ou outra destinação final ambientalmente adequada (BRASIL, 2010)

Com efeito, conforme lembra Amado (2014, p. 814), os fabricantes, importadores, distribuidores e comerciantes de agrotóxicos, seus resíduos e embalagens, assim como outros produtos cuja embalagem, após o uso, constitua resíduo perigoso, são obrigados a estruturar e implementar sistemas de logística reversa, mediante retorno dos produtos após o uso pelo consumidor, de forma independente do serviço público de limpeza urbana e de manejo dos resíduos sólidos.

Ressalte-se, por oportuno, que caberá aos consumidores promover a devolução após o uso, aos comerciantes ou distribuidores, dos produtos e das embalagens referidos. Por sua vez, os comerciantes e os distribuidores deverão efetuar a sua devolução aos fabricantes ou aos importadores, que finalmente darão destinação ambientalmente adequada aos produtos e às embalagens reunidos ou devolvidos, sendo o rejeito encaminhado para a disposição final ambientalmente adequada (Idem). 
De acordo com Leite (2000, p. 1), há, pois, uma nova área da logística empresarial que se preocupa em equacionar a multiplicidade de aspectos logísticos do retorno ao ciclo produtivo destes diferentes tipos de bens industriais e de seus materiais constituintes, bem como dos resíduos industriais, que ocorre por meio da reutilização controlada do bem e de seus componentes ou da reciclagem dos materiais constituintes, dando origem a matérias-primas secundárias que se reintegrarão ao processo produtivo.

Além disso, forçoso reconhecer que o pós-venda e o pós-consumo ganham gradativamente - maior importância nas estratégias de sustentabilidade e no crescimento dos negócios das empresas, que acabam aceitando previamente o retorno dos seus produtos dos consumidores finais, para uma possível reutilização, reciclagem no seu ciclo produtivo ou em outros ciclos, ou mesmo para a disposição final. (LAGARINHOS; TENÓRIO, 2012, p. 51)

Cumpre salientar que - conforme ressaltam Roger e Tibben-Lembke (1999) - a inclusão da logística reversa na reflexão estratégica das organizações constitui-se em uma nova e diferenciada visão de operação empresarial, resultando em melhoria de competitividade, apreciáveis retornos financeiros e consolidação de sua imagem corporativa.

Superada essa análise, o próximo capítulo cuidará de examinar se há efetiva aplicação das normas estabelecidas na Lei em tela, bem como os efeitos práticos da aplicação do manejo adequado dos resíduos sólidos, de acordo com PNRS, com vistas à obtenção de modelos sustentáveis que proporcionem a inclusão social gerada pelo método da reciclagem e outros aspectos secundários também resultantes dessa nova visão.

\section{SUSTENTABILIDADE E INCLUSÃO SOCIAL POR MEIO DO MANEJO ADEQUADO DOS RESÍDUOS SÓlIDOS: OS CATADORES E A RECICLAGEM, QUALIDADE DE VIDA, SAÚDE E DIGNIDADE}

A ideia de sustentabilidade, a ser tratada nessa oportunidade, está prevista na Constituição da República Federativa do Brasil (CF/88), chamada - conforme Milaré (2009, p. 147) - de "Constituição Verde", em razão do amplo espectro de proteção do macrobem ambiental, já que coloca em foco - com uma adequação inerente à alma nacional - a necessidade de se aprender a conviver harmoniosamente com a natureza, transmitindo por vários de seus dispositivos o complexo da tutela do meio ambiente ali pretendida. 
Trata-se, segundo Benjamin (2007, p. 57) de um inequívoco dever de não degradar, contraposto ao direito de explorar, inerente ao direito de propriedade, previsto no art. 5ㅇ, XXII, da $\mathrm{CF} / 88$.

O dever de proteção ambiental tem íntima relação com a dignidade humana, conforme estampado no caput do art. 225 da CF/88, que atribui ao Poder Público e à coletividade o dever de defendê-lo e preservá-lo às presentes e futuras gerações. Vê-se, assim, que se impõe ao Poder Público o exercício das competências para concretização do precitado direito fundamental, valendo-se, inclusive, para tanto, de medidas de poder de polícia e de implementação das políticas públicas, como a que se refere à administração dos resíduos sólidos, objeto do presente artigo.

Isso porque, como menciona Dworkin, apud Ohlweiler (2017, p. 306), os cidadãos - em determinadas situações - precisam da ordem que só um governo coercitivo pode providenciar, a fim de proteger e materializar o ideal de vida boa e de viver bem. Nesse viés, esse último autor ainda pondera o seguinte:

Por outro lado, é também do mau exercício de tais competências que surge a possibilidade de danos ao meio ambiente e aos próprios cidadãos, impondo-se cada vez mais desenvolver uma concepção jusambiental daquilo que é exigido pela dignidade do ambiente e dos cidadãos, cujo caráter normativo é interpretativo. O que deve a Administração Pública fazer e sobre o que não pode deixar de decidir? [...] No entanto, a efetividade do artigo 225 da Constituição Federal passa igualmente pela própria concepção de responsabilidade ambiental da comunidade, compreendendo que parte do ethos ambiental exige que os cidadãos devam aceitar e exigir dos outros a obrigação de cuidado ambiental [...].

Além disso, outro ponto que deve ser mencionado é o que encontra relação com o avanço já alcançado pela prestação do serviço de coleta seletiva pelos municípios brasileiros, conquanto ainda se encontre muito aquém dos patamares necessários para efetivamente reduzir a quantidade de resíduos que ainda são dispostos em aterros ou lixões e os impactos decorrentes, em que pese sejam potencialmente recicláveis.

A fim de evidenciar esse dever na prática, cumpre mencionar que cabe aos municípios a elaboração de planos integrados de gerenciamento que incorporem: a) Programa Municipal de Gerenciamento (para geradores de pequenos volumes); b) Projetos de Gerenciamento em obra (para aprovação dos empreendimentos dos geradores de grandes volumes), de modo a caracterizar os resíduos e indicar procedimentos para triagem, acondicionamento, transporte e destinação (CONAMA, 2002). 
Dado esse introito, torna-se imperioso salientar, a partir de agora, as noções de sustentabilidade e de desenvolvimento sustentável - compreendidas nas sociedades de risco e consideradas pelo Direito Ambiental como compromissos políticos, sociais e, sobretudo, jurídicos, de concretização de um mundo futuro possível - substituindo, assim, a equivocada perspectiva de promessa de segurança no futuro (AYALA, 2004, p. 234). Nessa perspectiva, surge, pois, um novo pacto do homem com a natureza: esta última não seria mais vista como um mero instrumento (meio) para se atingir o lucro (fim), acabando-se com a dicotomia sociedade-natureza, de maneira que o desenvolvimento sustentável implemente um desenvolvimento econômico social que atenda às necessidades atuais e não comprometa as necessidades das futuras gerações.

Atrelada a esse princípio, encontra-se a tão comentada crise vivenciada no setor que lida com o gerenciamento dos resíduos sólidos, considerada como consequência lógica dessa ótica de mercado, baseada no consumismo e desperdício, conceitos anteriormente comentados. Para se alcançar uma efetiva mudança, exigir-se-ia uma mudança radical do paradigma de produção prevalecente na cultura fundamentada na crescente acumulação de riquezas e efemeridade daquilo que se obtém; entretanto, sabe-se que essa perspectiva se revela ainda distante, eis que exige mudanças a longo prazo.

Acerca do tema dos resíduos sólidos, Jacobi (2006, p. 13) aloca tal seara provavelmente como a que melhor exemplifica as possibilidades de formulação de políticas públicas que promovam mudanças nos hábitos e atitudes dos cidadãos com o objetivo de minimizar ou prevenir a degradação ambiental. Entretanto, assevera que a timidez das políticas públicas, assim como a sua descontinuidade, tem criado um verdadeiro círculo vicioso: as diversas experiências bem sucedidas de gestão a partir de práticas mostram que é possível romper com o círculo vicioso existente e engajar a população em ações pautadas pela co-responsabilização e compromisso com a defesa do meio ambiente.

Em nenhum outro caso existem condições tão favoráveis para estabelecer vínculos entre a atividade humana e o sistema ecológico como quanto à forma como uma sociedade administra os dejetos que produz. Esse argumento - trazido pelo autor supramencionado transcende o aspecto específico da gestão dos resíduos sólidos e abre um vasto campo de aprofundamento em torno dos meios e fins para atingir algum grau de sustentabilidade ambiental (JACOBI, 2006, p. 13).

Ainda, segundo Jacobi (2012, p. 31), 
um dos desafios é a necessidade e definirmos as melhores alternativas a serem adotadas, com menores impactos e que não sejam meramente tecnológicas, colocando a inclusão social como um tema fundamental, que deve ser tratado sem paternalismos, como parte de uma política publica visando promover a redução das desigualdades, pois todos nós estamos envolvidos, principalmente nas ideias de se produzir menos, de reutilização e de reciclagem.

Dessa forma, conquanto não se ignore a verdadeira causa da mencionada crise, considerar-se-ão - nessa oportunidade - as vias de enfrentamento que prestigiem a sustentabilidade e que se apresentem ao menos palpáveis e passíveis de serem colocadas em prática.

Oportuno ressaltar que as opções de destinação final para os resíduos são inegavelmente limitadas, pelo que se faz imprescindível minimizar as quantidades produzidas por meio da redução, reutilização e reciclagem, nos termos da PNRS. O estímulo à redução dos resíduos sólidos se concretiza por meio de práticas relacionadas a programas de ações de Educação Ambiental (EA), a qual é considerada instrumento da Política Nacional de Resíduos Sólidos (art. 8ำ, VIII, LPNRS).

Nessa toada, ainda acerca da sustentabilidade, tem-se - como relevante meio de proporcioná-la - a utilização do método da reciclagem. Isso porque - juntamente a essa medida benéfica de transformação dos materiais em algo útil, em nítida colaboração com o meio ambiente - surgem outras consequências que trazem igualmente resultados socialmente relevantes, como a inclusão social dos profissionais que lidam com os lixões, catadores de materiais recicláveis, qualidade de vida, saúde e dignidade dessa população tão excluída.

Portanto, existe uma tendência geral ao aproveitamento desses resíduos por meio da reciclagem, considerando-se o imenso valor potencial dos plásticos e as implicações dos desperdícios e poluição decorrentes de não utilização desses resíduos (FORLIN; FARIA, 2002).

Nesse passo, a Resolução 275/ 2001 estabelece que a reciclagem de resíduos deve ser incentivada, facilitada e expandida no país, para reduzir o consumo de matérias-primas, recursos naturais não-renováveis, energia e água; a necessidade de reduzir o crescente impacto ambiental associado à extração, geração, beneficiamento, transporte, tratamento e destinação final de matérias-primas, provocando o aumento de lixões e aterros sanitários; que as campanhas de educação ambiental (EA), providas de um sistema de identificação de fácil visualização, de validade nacional e inspirado em formas de codificação já adotadas internacionalmente, sejam essenciais para efetivarem a coleta seletiva de resíduos, viabilizando a reciclagem de materiais. 
Com supedâneo no princípio do reconhecimento do valor do resíduo sólido reutilizável e reciclável, dessume-se que "a obrigação legal prioritária de não gerar resíduo mostra fortemente a reutilização e a reciclagem como as opções da política brasileira de resíduos sólidos" (MACHADO, 2012, p. 30). Desse modo, verifica-se que - de acordo com o art. 3ㅇ da Lei n. 12.305/2010 - a reutilização é processo de aproveitamento dos resíduos sólidos sem sua transformação biológica, física ou físico-químicas ou biológicas, com vistas à transformação em insumos ou novos produtos; a diferença, portanto, reside na necessidade ou não de se transformar a matéria com emprego de meios biológicos, físico-químicos ou biológicos.

Ademais, cumpre frisar que a implementação de programas de coleta seletiva é fundamental para o equacionamento dos impactos que os resíduos sólidos provocam no ambiente e na saúde dos cidadãos. A produção de resíduos sólidos é crescente, e a sua destinação ainda é adequada em grande parte dos municípios brasileiros. A coleta seletiva promove sua redução na fonte geradora, o reaproveitamento e a reciclagem de matériasprimas, a geração de renda com inclusão social, assim como também minimiza o impacto ambiental causado pelo aterramento dos resíduos.

Sabe-se que os personagens envolvidos nesse cenário de "sobrevivência no/do lixo" sentem de forma direta os efeitos dessa mazela, já que praticam uma das atividades consideradas mais insalubres, degradantes, desvalorizadas e indignas, fortemente estigmatizadas. Nas palavras Maia, Guimarães e Severo (2017, p. 2016): “[...] a profissão de catador de material de reciclável é estigmatizada socialmente, mesmo quando o estigmatizador não tenha consciência disto", uma vez que - no imaginário social - o catador de material reciclável, para coletar o objeto de seu trabalho, precisa revirar o lixo ou estar em lixões.

São pessoas - na maioria das vezes - excluídas do convívio social por conta de suas condições e encontram no lixo produzido pela sociedade seu sustento. Esta categoria social é composta de homens, mulheres e crianças, em sua maioria com baixa escolaridade e baixo poder aquisitivo; apesar destas condições, são foco da Política Nacional de Resíduos Sólidos, que preza pela inclusão social e desenvolvimento econômico destas pessoas.

Ocorre que - mesmo com a vigência da Lei da PNRS, consoante lembram Maia et al (2017, p. 2009) - não se vislumbra uma melhora significativa da situação do catador de material reciclável em todos os municípios brasileiros, visto que "muitos destes não conseguiram se enquadrar na PNRS, cuja consequência culminou no projeto de lei que prorroga o prazo inicial de quatro anos para por fim aos lixões". 
Ademais, conforme já mencionado anteriormente, o referido Projeto de Lei - que aumenta o prazo para o fim dos lixões e aterros controlados - consequentemente, dilata a promoção da implantação da coleta seletiva realizada pelo catador, bem como sua autonomia financeira (SEVERO e CUNHA, 2016).

Impende registrar que a própria nomenclatura "lixo", por si só, já se revela estigmatizadora, razão por que seria mais adequado utilizar a denominação "catador de material reciclável", em vez de catador de lixo. Infere-se, assim, que a situação desses personagens se insere no contexto já institucionalizado de vulnerabilidade, precariedade e fragilidade das condições de trabalho dos catadores (GONÇALVES-DIAS, 2009).

Conforme informação trazida no site da ONU (2016), os catadores de materiais recicláveis são os principais atores na recuperação de resíduos para a indústria de reciclagem, sendo que - entre suas demandas - está o reconhecimento dos serviços que prestam o acesso aos resíduos e o direito de concorrer a contratos de gestão, o que tem feito com que o Banco Mundial desenvolva programas para reconhecer e apoiar os catadores como integrantes do setor de resíduos sólidos.

Nesses termos, estabelece Gouveia (2012, p. 1507) que os catadores de materiais recicláveis além de serem os grandes protagonistas da indústria de reciclagem no país, detêm posição fundamental na gestão de resíduos sólidos no Brasil, à medida que sua própria existência indica a dificuldade de incluir no gerenciamento desse sistema as atividades de catação, principalmente por problemas de escala de produção combinados a dificuldades logísticas. Esse grupo de trabalhadores vem atuando de maneira informal ou organizada em cooperativas e - mesmo antes da definição de políticas públicas claras para a gestão de resíduos no país - vem realizando um trabalho de grande importância ambiental, de maneira a contribuir significativamente para o retorno de diferentes materiais para o ciclo produtivo e a gerar economia de energia e de matéria-prima, evitando que diversos materiais sejam destinados a aterros.

Importa ressaltar, nesse contexto, a relevância dos efeitos oriundos da valorização desse profissional, uma vez que esse - ao se organizar coletivamente - pode fomentar, entre seus pares, a epistemologia ambiental popular, portanto, indo além do caráter inicial que seria a subsistência (MAIA et. al., 2017, p. 2006).

Segundo Ferraz et. al. (2012, p. 15), o poder municipal - enquanto agente que necessita se adequar à Lei Nacional de Resíduos Sólidos - visa à valorização do catador não só enquanto um importante elo da cadeia de gestão dos resíduos, mas também pela necessidade de que a 
atividade por ele exercida seja repassada aos indivíduos que se identifiquem com a proposta do empreendedorismo e passem a investir na exploração do resíduo por meio da abertura de empresas de reciclagem, visto que os próprios catadores não aderem aos programas públicos, em virtude de falta da regulamentação da profissão do catador.

Os referidos autores elaboraram uma interessante análise acerca da Política Pública da Sustentabilidade Ambiental e Humana (PPSAH), exemplo prática de uma política pública de promoção, cuja proposta consiste em criar condições de geração de trabalho e renda e, concomitantemente, viabilizar a gestão dos resíduos sólidos da cidade. Sucintamente o documento apresentado pela prefeitura menciona que o projeto implantado em 2007, SAH reciclagem inclusão total, tem como princípio o "reconhecimento e valorização do catador como um importante elo na cadeia de reciclagem" (FERRAZ et. al, 2002, p. 9)

Consoante comenta Ribeiro (2009, p. 22), desde 1989, multiplicam-se no Brasil as experiências de gestão compartilhada de resíduos sólidos por meio de programas municipais de coleta seletiva em parceria com catadores de materiais recicláveis organizados em associações e corporativas, experiências que devem ser valorizadas, apesar da sua pequena escala, porque geram benefício econômico (garantia de renda estável às famílias envolvidas); benefício ambiental (reciclagem de diversos materiais) e benefício social, pois esse trabalho proporciona possibilidades de integração social de pessoas que sempre foram marginalizadas.

Nesse contexto, ressaltam Garcia e Campidelli (2016, p. 92), no que concerne a essa classe tão excluída, que - em 1994, no relatório da Organização das Nações Unidas para a Educação, a Ciência e a Cultura (UNESCO) sobre o desenvolvimento Humano - demonstrou-se que: "nas sociedades pobres, o que está em risco não é a qualidade de vida, mas a própria vida". Isso demonstra que a diminuição da extrema pobreza desde 1994 não deixou de ser uma preocupação na realidade brasileira, segundo a qual - apesar de já ter diminuído muito a quantidade de pessoas na extrema pobreza após o início da intervenção Estatal de redistribuição de renda - a desigualdade ainda constitui fator notório, e o que se visualiza na prática é que essas pessoas ainda vivem em situação degradante e são extremamente dependentes desse pequeno recurso do Estado.

O Movimento Nacional dos Catadores de Materiais Recicláveis procura pautar suas intervenções na realidade por meio do incentivo ao protagonismo social:

Nosso objetivo é garantir o protagonismo popular de nossa classe, que é oprimida pelas estruturas do sistema social. Temos por princípio garantir a independência de classe, que dispensa a fala de partidos políticos, governos e empresários em nosso nome. Acreditamos na prática da ação 
direta popular, que é a participação efetiva do trabalhador em tudo que envolve sua vida, algo que rompe com a indiferença do povo e abre caminho para a transformação da sociedade (MNCR, site do movimento).

Devem ser trazidos à baila alguns Projetos que representam uma tentativa de cumprir com a proposta de redução da produção de resíduos sólidos, por meio da Educação Ambiental (EA) e de medidas que estimulem as empresas, por exemplo, não só a reduzir a criação desenfreada de resíduos sólidos, mas também proceder à sua adequada destinação: além do Projeto Respira São Paulo, o governo do Estado de São Paulo estabeleceu 21 projetos ambientais estratégicos, dentre eles o denominado Lixo Mínimo. Conforme lembra Sirvinskas (2015, p. 506-507), a CETESB, com base nisso, vem divulgando o inventário estadual dos resíduos sólidos com a posição atual da destinação de resíduos urbanos nos municípios de São Paulo desde 1997. Tal inventário é publicado anualmente no DOE com a denominação Inventário Estadual de Resíduos Domiciliares - Índice de Qualidade de Aterros de Resíduos no Estado de São Paulo - IQR.

Esses dados são importantes para demonstrar que o Estado de São Paulo já havia tomado a dianteira para acabar com os lixões, especialmente com a certificação denominada Verde Azul, concedida aos municípios. Ademais, cumpre salientar que o Ministério Público do Estado de São Paulo (MP/SP) também contribuiu para diminuir os lixões, tendo inserido no seu plano de atuação, na área de urbanismo e meio ambiente de 2007 a 2008, oito novas prioridades para atuação em áreas finalísticas. São elas: a) coleta, afastamento e tratamento de esgoto; b) reserva legal e áreas de preservação permanente; c) controle e uso do solo urbano com ênfase nas áreas de risco ocupadas; d) extinção dos "lixões" (adequação da destinação dos resíduos sólidos); e) controle do uso e ocupação do solo rural, com ênfase nas monoculturas (cana e eucalipto); f) acompanhamento na elaboração dos planos de manejo e efetiva implementação das unidades de conservação; g) acompanhamento da elaboração de planos diretores municipais; h) águas subterrâneas (proteção das áreas de recarga e controle da exploração).

Dessa forma, o Ministério Público passou - com o fim de tutelar o direito ao meio ambiente ecologicamente equilibrado - a propor Ações Civis Públicas e instaurar Inquéritos Civis ou firmar Termos de Ajustamento de Conduta com as diversas prefeituras do Estado. Nesse viés, Sirvinskas (2015, p. 506-507) sinaliza, portanto, que o esforço deve ser concentrado e compartilhado para que o resultado seja efetivo e eficaz, e assim o será quando se focar realmente na amenização das causas da crise (manutenção do modelo predatório de produção da vida, segundo o qual se busca o lucro a todo custo, sem preocupação com o ambiente). 
Caso se continue a tratar tão somente das consequências, de forma simplista, permitirse-á que os malefícios sejam sempre os mesmos.

\section{CONSIDERAÇÕES FINAIS}

É possível afirmar que - com o aumento significativo da população mundial evidenciou-se uma maior necessidade de uso dos recursos naturais disponíveis do meio ambiente, o que significa uma sobrecarga de uso e - por conseguinte - uma incapacidade de renovação natural de tais recursos ambientais.

Esse crescimento populacional - aliado à adoção do sistema consumista avançado, baseado na exacerbação do consumo e do descarte - é reputado como fonte da crise socioeconômica e socioambiental, manifestada, inclusive, mediante a produção desenfreada de resíduos sólidos.

Considerando que as pessoas - adeptas à cultura do consumo em virtude do modelo de produção imposto, baseado no acúmulo de riquezas - produzem uma média diária de um quilograma de "lixo" (expressão considerada etimologicamente inadequada, conforme demonstrado ao longo do trabalho, ante a possibilidade de reutilização e reciclagem de sua grande maioria), a situação se torna cada vez mais preocupante, exigindo uma reflexão e ações mais profundas sobre as vias de enfrentamento aos hábitos de desperdício e demais efeitos decorrentes desse consumismo irresponsável.

Nota-se, portanto, que - uma vez encarada a existência de um cenário alarmante no que concerne ao serviço público de gestão dos resíduos sólidos - a presente proposta visa o combate à apatia que entende como normal a situação instalada práticas para suplantação baseadas na sustentabilidade: vê-se, pois, a tentativa de desestímulo ao desperdício, a não produção excessiva de resíduos sólidos, por meio da educação ambiental, a reciclagem, logística reversa e valorização dos catadores como agentes transformadores da realidade.

Verifica-se que o principal problema hoje vivenciado é justamente a ausência de uma forma eficaz de lidar com essa enxurrada de resíduos sólidos produzidos diariamente pela população e que o município não dá conta de gerir de uma maneira satisfatória, o que demanda a adoção de uma nova postura de gerenciamento que efetivamente incorpore a ideia de sustentabilidade.

Não se pode olvidar que não só a grande quantidade gerada, mas também a má gestão dos resíduos sólidos, resultam em evidentes riscos à população, o que provoca gastos 
financeiros significativos, constituindo-se não só em fatores de degradação ambiental, como também em problemas de saúde pública, o que justifica a necessidade de maior atenção aos processos de preservação e recuperação ambiental para uma correta gestão dos resíduos.

Sobre os Resíduos Sólidos Urbanos (RSU), foi possível constatar que, institucionalmente, ocorreram avanços - especialmente a partir do marco legal - entre os quais é possível citar a instituição da responsabilidade compartilhada dos geradores de resíduos, baseada no instituto da Logística Reversa; outrossim, tem-se a inclusão de catadores de materiais recicláveis e reutilizáveis, com geração de emprego, renda e cidadania desses importantes personagens, tanto em virtude da Logística Reversa quanto da Coleta Seletiva.

A consolidação da PNRS só se dará quando da estruturação dos Planos Integrados de Gestão de Resíduos Sólidos (PIGRS) e da sua efetivação, o que demanda um profundo movimento político-institucional e técnico-educacional em diversos segmentos.

Na ordem de prioridade estabelecida pela PNRS, a redução dos resíduos sólidos é a primeira medida a ser estabelecida, em confronto com o paradigma da sociedade "líquidomoderna", o consumismo e o desperdício como principais fatores do sistema de consumo atual e sua forte influência na crescente quantidade de resíduos sólidos. Após a verificação da origem dessa crise, ressaltou-se a relevância da Política Nacional de Resíduos Sólidos, que encontra supedâneo da Lei n. 12.305/2010 e deve ser utilizada como ferramenta no enfrentamento dos principais problemas ambientais, sociais e econômicos decorrentes do manejo inadequado dos resíduos sólidos.

A referida legislação ainda não conseguiu ser plenamente aplicada da forma como conjecturada, em virtude do magma de dificuldades para sua efetiva implantação; contudo, restou apurado que a sustentabilidade, a inclusão social, o manejo adequado dos resíduos sólidos, diante da emergente institucionalização da PNRS, são medidas que visam a evitar a reprodução do efeito perverso da exclusão e da exploração nesse segmento de trabalhadores informais; nessa perspectiva, faz-se imprescindível delinear políticas públicas que articulem aspectos sociais (saúde, segurança do trabalho, autogestão, cidadania, inclusão entre outras), econômicos (geração de renda, redução de custos, mercado entre outros) e técnico-ambientais (qualidade, eficiência, entre outras), de modo a tornar a atividade de catação mais digna e com menos riscos e - ao mesmo tempo - garantir a geração de renda e riqueza, com a inclusão social desse relevante segmento de trabalhadores. 


\section{REFERÊNCIAS BIBLIOGRÁFICAS}

ABRELPE. Panorama dos Resíduos Sólidos de 2016. Disponível em: <http://www.abrelpe.org.br/Panorama/panorama2016.pdf>. Acesso em: 02 nov. 2017.

AMADO, Frederico Augusto Di Trindade. Direito ambiental esquematizado. 5 ed. Rio de Janeiro: Forense; São Paulo: Método, 2014.

AYALA, Patryck de Araújo. A proteção jurídica das futuras gerações na sociedade do risco global: o Direito ao Futuro na Ordem Constitucional Brasileira. In Estado de direito ambiental: tendências. Aspectos constitucionais e diagnósticos. Org.: Heline Sivini Ferreira. José Rubens Morato Leite; autores Alexandra Aragão... [et al]. - Rio de Janeiro: Forense Universitária, 2004.

BAUDRILLARD, Jean. A sociedade de consumo. 2 ed. Portugal: Edições 70, 2008.

BAUMAN, Zygmunt. Entrevista dada ao jornal espanhol La Vanguardia (2014). Disponível em: <http://www.lavanguardia.com/vida/20140517/54408010366/zygmunt-bauman-dificilencontrar-feliz-ricos.html>. Acesso em: 18 set. 2017.

BAUMAN, Zygmunt. Vida líquida. Tradução Carlos Alberto Medeiros. Rio de Janeiro: Zahar, 2007. Vidas Desperdiçadas. Tradução Carlos Alberto Medeiros. Rio de Janeiro: Zahar, 2005.

Vida para consumo: a transformação das pessoas em mercadoria. Tradução Carlos Alberto Medeiros. Rio de Janeiro: Zahar, 2008.

BENJAMIN, Antonio Herman. Constitucionalização do Ambiente e Ecologização da Constituição Brasileira. In Direito constitucional ambiental brasileiro. José Joaquim Gomes Canotilho, José Rubens Morato Leite (organizadores). São Paulo: Saraiva, 2007.

BRASIL. Lei n. 12.305, de 02 de agosto de 2010. Disponível em: <http://www.planalto.gov.br/ccivil_03/_ato2007-2010/2010/lei//12305.htm>. Acesso em: 10 ago. 2017.

BRASIL. Resolução Conama n. 275, de 25 de abril de 2001. Disponível em: <http://www.mma.gov.br/port/conama/legiabre.cfm?codlegi=273>. Acesso em: 10 ago. 2017.

BRASIL. Resolução Conama n. 307, de julho de 2002. Disponível em: <http://www.mma.gov.br/port/conama/legiano.cfm?codlegitipo=3>. Acesso em: 18 out. 2017.

BROLLO, Maria José. Política e gestão ambiental em resíduos sólidos. Revisão e análise sobre a atual situação no Brasil. 21. Congresso Brasileiro de Engenharia Sanitária e Ambiental. Disponível em: <https://www.researchgate.net/publication/228885347>. Acesso em: 10 set. 2017.

COLEN, Suzana Beatriz Sena Teixeira; GOMES, Magno Federici. Possibilidades legislativas na condução e minimização dos problemas gerados pelos resíduos sólidos no Brasil. Argumenta Journal Law, Jacarezinho - PR, Brasil, n. 26. p. 265-286. 
CORTEZ, A.T.C.; ORTIGOZA, S.A.G., orgs. Da produção ao consumo: impactos socioambientais no espaço urbano [online]. São Paulo: Editora UNESP; São Paulo: Cultura Acadêmica, 2009. 146 p. ISBN 978-85-7983-007-5. Disponível em: SciELO Books <http://books.scielo.org>. Acesso em: 14 set. 2017.

COSTA, Ilton Garcia da; MONTE, William R. Alkema; DEMARCHI, Clovis . Considerações sobre a Gestão de Residuos Sólidos no Brasil. In: Gabriel Real Ferrer; Marcelo Buzaglo Dantas; Maria Claudia da S. Antunes de Souza. (Org.). Sustentabilidade e suas Interações com a Ciência Jurídica. 1ed.Itajai: Univali, 2016, v. 1, p. 202-223.

COSTA, Ilton Garcia da; MONTE, William R. Alkema; DEMARCHI, Clovis; GODOY PULCINELLI, Ana Luiza. Imigrantes: uma análise crítica dos serviços públicos adotados para a sua inserção no mercado de trabalho - 10.12818/p.0304-2340.2017v71p243. Revista da Faculdade de Direito Universidade Federal de Minas Gerais, v. 71, p. 243-267, 2018.

COSTA, Ilton Garcia da; MONTE, William R. Alkema; DEMARCHI, Clovis; CAMPIDELLI, Laísa Fernanda. A diminuição da extrema pobreza, baseada em políticas públicas eficazes e garantia do mínimo existencial. In: CACHICHI, R. C. D; COSTA, I. G. da; LEÃO JÚNIOR, T. M. de A. Paz, constituição e políticas públicas - Vol. II. Organizadores: Ilton Garcia da Costa, Rogério Cangussu Dantas Cachichi, Teófilo Marcelo de Arêa Leão Júnior. Curitiba: Instituto Memória. Centro de Estudos da Contemporaneidade, 2016. 236 p.

CUNHA, Paulo. A globalização, a sociedade de risco, a dimensão preventiva do Direito e o Ambiente. In Estado de direito ambiental: tendências. Aspectos constitucionais e diagnósticos. Org.: Heline Sivini Ferreira. José Rubens Morato Leite; autores Alexandra Aragão... [et al]. - Rio de Janeiro: Forense Universitária, 2004.

FERRAZ, Deise Luiza da Silva; SILVA, Pedrina Viana da; MUELLER, Rafael Rodrigo; REIS, Marx Rodrigues dos. A análise de uma Política Pública de Geração de Trabalho e Renda por meio da discussão dos Reguladores Sociais Lukacsiano: o caso dos Catadores de Materiais Recicláveis. XXXVI Encontro da ANPAD. Rio de Janeiro: 2012.

FERREIRA, Aurélio Buarque de Holanda. Novo dicionário da Língua Portuguesa. 2 ed. Rio de Janeiro: Nova Fronteira, 2001.

FIORILLO, Celso Antonio Pacheco. Curso de Direito Ambiental brasileiro. 12 ed. São Paulo: Saraiva, 2011.

FORLIN, F. J.; FARIA, J. Considerações sobre a reciclagem de embalagens plásticas. Polímeros: Ciência e Tecnologia, v. 12, n. 1, p. 1-10, 2002.

GONÇALVES-DIAS, S.L.F. Catadores: uma perspectiva de sua inserção no campo da indústria de reciclagem [tese]. São Paulo: Universidade de São Paulo, 2009.

GOUVEIA, Nelson. Resíduos sólidos urbanos: impactos socioambientais e perspectiva de manejo sustentável com inclusão social. Ciênc. saúde coletiva [online]. 2012, vol.17, n.6, pp.1503-1510. 
ISSN 1413-8123. Disponível em: <http://dx.doi.org/10.1590/S1413-81232012000600014>. Acesso em: 11 set. 2017.

HARVEY, D. Condição pós-moderna: uma pesquisa sobre as origens da mudança cultural. 7. ed. São Paulo: Edições Loyola, 1992.

INSTITUTO AKATU. Responsabilidade Social das Empresas e a Percepção do Consumidor Brasileiro. $2010 . \quad$ Disponível em: <http://www.akatu.org.br/Content/Akatu/Arquivos/file/10_12_13_RSEpesquisa2010_pdf .pdf>. Acesso em: 01 out. 2017.

JACOBI, Pedro. Desafios e reflexões sobre resíduos sólidos nas cidades brasileiras. In: SANTOS, M. C.L; DIAS, S. L. F. (orgs.) Resíduos Sólidos Urbanos e seus impactos socioambientais. São Paulo: IEE-USP, 2012.

JACOBI, Pedro. Gestão compartilhada dos resíduos sólidos no Brasil: inovação com inclusão social. Org. de Pedro Jacobi. São Paulo: 2006, Annablume.

KENNEDY, Paul. Preparando para o século XXI. São Paulo: Campus, 1996.

LAGARINHOS, Carlos A. F.; TENÓRIO, Jorge A. S. Logística Reversa dos Pneus Usados no Brasil. EPUSP. Polímeros [online]. 2013, vol.23, n.1, pp.49-58. Epub, 2012. ISSN 0104-1428. Disponível em: <http://dx.doi.org/10.1590/S0104-14282012005000059>. Acesso em: 18 out. 2017.

LEFF, H. Saber ambiental: sustentabilidade, racionalidade, complexidade e poder. Petrópolis: Vozes, 2001.

LEITE, Paulo Roberto. Logística Reversa: Meio Ambiente e Competitividade. 1.ed. São Paulo: Prentice Hall, 2000.

MACHADO, Paulo Affonso Leme. Direito Ambiental Brasileiro. 21. ed. São Paulo: Malheiros, 2013.

MACHADO, Paulo Affonso Leme. Princípios da política nacional de resíduos sólidos. Revista do Tribunal Regional Federal da 1a Região, v. 24, n. 7, jul. 2012. Disponível em: <https://core.ac.uk/download/pdf/16037203.pdf>. Acesso em 19.09.2017.

MAGALHÃES, Ligia Maria. Lixo e desperdício, perspectiva numa sociedade de consumo. Trabalho de Monografia pós-graduação. Rio de Janeiro, 2002.

MAIA, Fernando Joaquim Ferreira; GUIMARÃES, Patrícia Borba Vilar. SEVERO, Ana Luiza Felix. O estigma da atividade de catador de material reciclável no ambiente urbano: uma análise na ótica de Erving Goffman sobre o "lixo extraordinário". Revista de Direito da Cidade, vol. 09, o 4. ISSN 2317-7721 pp. 2002-2022. Disponivel em: <http://www.epublicacoes.uerj.br/index.php/rdc/article/view/29458>. Acesso em: 12 dez. 2017.

MILARÉ, Edis. Direito do ambiente: doutrina, jurisprudência, glossário. 6. ed. São Paulo: Revista dos Tribunais, 2009. 
MNCR. Movimento Nacional de Catadores de Recicláveis. Disponível em: <http://www.mncr.org.br/>. Acesso em: 05 nov. 2017.

OHLWEILER, Leonel Pires. A responsabilidade do Estado por danos oriundos de enchentes e o direito dos desastres: a efetividade do dever de cuidado administrativo no Estado de Direito ambiental. Argumenta Journal Law: Jacarezinho - PR, Brasil, 2017, n. 26. p. 287-336.

ONU. Organização das Nações Unidas. 2016. Disponível em: <https://nacoesunidas.org/umcirculo-virtuoso-a-integracao-de-catadores-na-gestao-de-residuos-solidos/>. Acesso em: 02 nov. 2017.

NASCIMENTO, Raphael Motta; PINTO, Augusto Eduardo Miranda. Sustentabilidade e precaução: uma avaliação do plano municipal de gerenciamento de resíduos de Macaé referenciados na Política Nacional de Resíduos Sólidos. Revista de Direito da Cidade, [S.I.], v. 10, n. 1, p. 78-94, jan. 2018. ISSN 2317-7721. Disponível em: <http://www.epublicacoes.uerj.br/index.php/rdc/article/view/29600>. Acesso em: 10 fev. 2018. doi:https://doi.org/10.12957/rdc.2018.29600.

PNUMA. Programa das Nações Unidas para o Meio Ambiente. Disponível em: <http://www.unmultimedia.org/radio/portuguese/2012/11/onu-diz-que-mundo-sofre-ameacade-crise-global-de-lixos-urbanos/>. Acesso em: 09 out. 2017.

PADILHA, Valquiria. Obsolescência planejada: armadilha silenciosa na sociedade de consumo. 02.09.2013 Disponível em <http://diplomatique.org.br/obsolescencia-planejada-armadilhasilenciosa-na-sociedade-de-consumo/>. Acesso em: 02 out. 2017.

RIBEIRO, H. JACOBI, P.R. BESSEN, G.R; GÜNTER, W.M.R; DEMAJOROVIC, J. VIVEIROS, M. Coleta Seletiva com inclusão social: cooperativismo e sustentabilidade. São Paulo: Annablume, 2009.

ROGERS, D. S.; TIBBEN-LEMBKE, R. S. Going backwards: reverse logistics trends and practices. University of Nevada: Reno, 1999.

ROTHENBURG, Walter Claudius. Direitos Fundamentais. Rio de Janeiro: Forense, 2014.

SENADO FEDERAL. Resíduos Sólidos: Lixões persistem. Revista Em discussão! Ano 5 - № 22 setembro de 2014.2 Disponível em: <https://www12.senado.leg.br/emdiscussao/edicoes/residuossolidos/@@images/arquivo_pdf/>. Acesso em: 10 jan. 2018.

SEVERO, Ana Luíza Félix; CUNHA, Belinda Pereira. Catador de material reciclável: cidadania e o direito social à previdência especial. XXV Encontro Nacional do Conpedi - Brasília/DF. Direito ambiental e socioambientalismo I. Coordenadores: Belinda Pereira da Cunha, Fernando Antonio De Carvalho Dantas, Maria Nazareth Vasques Mota - Florianópolis: CONPEDI, 2016. Disponível em: <http://www.conpedi.org.br/publicacoes/yOii48h0/342787w4>. Acesso em: 20 jan. 2018.

SIMÕES, Priscila F. Conferências e acordos mundiais sobre meio ambiente: publicidade, consumo e sustentabilidade. In: Inclusão social: desenvolvimento sustentável e meio ambiente: Simpósio 
ISO CERTOS 2016: volume 2 /IIton Garcia da Costa, Soraya Saad Lopes, Diego Nassif da Silva, organizadores - 1. Ed. Bandeirantes, PR: Redige Produção Editorial, 2016.

SIRVINSKAS, Luís Paulo. Manual de Direito Ambiental. 13 ed. São Paulo. Saraiva, 2015.

ZANETI, Izabel Cristina Bruno Bacellar; SÁ, Laís Mourão; ALMEIDA, Valéria Gentil. Insustentabilidade e produção de resíduos: a face oculta do sistema do capital. Soc. estado. [online]. 2009, vol.24, n.1, pp.173-192. Disponível em: <http://www.scielo.br/scielo.php?script=sci_arttext\&pid=S0102> . Acesso em: 09 nov. 2017.

Trabalho enviado em 29 de janeiro de 2018.

Aceito em 25 de abril de 2018. 